\title{
Berry's Bringing It to the Table: A call to honor farming and food
}

\author{
Book Review: Bringing It to the Table: On Farming and Food by Wendell Berry
}

Wendell Berry (2009). Berkeley, CA: Counterpoint. ISBN 978-1-58243-543-5. 256 pp. \$14.95, trade paperback.

Dawn Thilmany McFadden, Colorado State University

Citation: Thilmany McFadden, D. (2010, November). Berry's Bringing It to the Table: A call to honor farming and food. [Review of the book Bringing It to the Table: On Farming and Food, by W. Berry]. Journal of Agriculture, Food Systems, and Community Development, 1:2, advance online publication. doi:10.5304/jafscd.2010.012.006

Published online 29 November 2010

Copyright (C) 2010 by New Leaf Associates, Inc.

Forty years of Wendell Berry's essays and excerpts from his fiction are gathered in Bringing It to the Table: On Farming and Food, providing some interesting historical, critical and thoughtful insights into what has shaped farming and food over these past decades. As a testament to the breadth of ideas that Berry expresses on American agriculture and food, you find chapters with names as varied as "A Defense of the Family Farm," "The Soil and Health," "Renewing Husbandry," and "The Pleasures of Eating." For those previously unfamiliar with Berry and his writing, this compilation is a perfect introduction to his ongoing conversation

Dawn Thilmany McFadden is a professor of agribusiness and an agribusiness extension economist with Colorado State University. She also serves on the Markets Advisory Board and Farmers Market Working Group and is a past Farm Foundation Fellow. Dawn's research and extension focus on two distinct areas of inquiry: small agribusiness management and local-food entrepreneurs as a part of rural development. In her Extension role, she currently leads a local food systems initiative for CSU Extension, and co-leads the CSU teams for the Northern Colorado Regional Food Assessment and Colorado Building Farmers program. with the public on the perils of a agricultural system that is not in balance with its ecosystem and communities. Michael Pollan sums it up well in his introduction: "[Berry's] now-famous formulation, 'eating is an agricultural act' is perhaps Berry's... signal contribution to the rethinking of food and farming under way today" (p. xiv).

Bringing It to the Table is divided into three sections. In "Farming," the essays (written between 1971 and 2004) provide a compelling review of the central argument of all Berry's work, while the second section, "Farmers," is made up of seven essays that describe his vision of "true farmers," who are innovating rather than adopting what the agribusiness sector sells with the marketing message of efficient production. Finally, the third section, "Food," includes excerpts from Berry's fiction: people sitting down to eat the food they have planted, raised, harvested, cooked, and served. His concepts are illustrated by the cover image of Grant Wood's Dinner for Threshers.

One of the interesting perspectives Berry adds to the food system discussion is his summary of the "displacement of a portfolio or energies and skills." 
These words, from 1979 and found on pages 63 and 64 , are at the core of many current debates on the balance of payments that the farming sector has with the earth's resources. Even in 1979, he warned against the move away from solar energy, as cover crops could capture more of the sun's energy year-round; animal energy, in a critique of confinement systems; human energy and skills, which may make the human capital that was gained in agricultural arts obsolete; and finally, soil and soil health. For the latter, he argues that in achieving scale efficiencies and advanced production technologies, we may have lost the customized practices and place-based knowledge needed to produce in the context of our agronomic natural assets.

Along these lines, he is critical of the land grant system's role in promoting "sound and prosperous rural life" (p. 39) at a time when its programs often pointed to practices and technologies that were dependent on purchased inputs and specialized technology from outside communities, rather than optimizing returns to the energy, resources, and people within farm-based communities. The message to the reader, whether a professional or a member of the food consumer community, is that we must pay close attention to how the system is structured and what it means for where food dollars flow: the types of energy, types of human capital, and where "reinvestments" may or may not be made in our natural resource base and communities.

In a 2002 piece, he envisions "stable, locally adapted resource-preserving communities," and goes on to say that committed consumers could support balanced plant and animal systems with their purchases. This seems to have framed the reemergence of local food systems we see engaging the public today. As a word of caution, he noted early on (1978) the absolute dependence of most of the population on industrial agriculture-and the lack of any backup system. With a large urban population that has no knowledge of how to grow food, no land, and few food-preparation skills, he saw the food-security implications for developed countries far before they entered the mainstream consciousness, when most were only concerned about malnutrition in the developing world.

Berry is unique in that he has always highlighted the characteristics of good farmers in his work, an aspect that influenced other contemporary writers such as Pollan. In his essays on farmers, he returns to his themes of promoting the arts of agriculture and the need for balance in resource use. In "Renewing Husbandry," he notes that "our recent focus upon productivity, genetic and technological uniformity and global trade...has obscured the necessity for local adaptation." In another work, he uses the word "sustainable" to describe farmers who waste nothing as they recognize their interaction and interdependence with their ecosystem, and maintain the cycle of natural resource use and replenishment.

Finally, Berry is unique in his lifting up of Eating as an essential element of society, as highlighted in his writings in the third section of this book. He talks about food politics vs. food esthetics vs. food ethics to highlight how we can't let our concerns about food production and security interfere with our enjoyment of food. He returns to the theme of agricultural and culinary arts versus the industrial themes of consumer transactions. When our time at meals is discounted by talk of costs and nutritional matrices, perhaps we are not valuing food as the social fabric it can be in our households and communities.

This book is perhaps the most valuable in its historical framing of how current food issues and debates are actually founded on concerns that have been raised for many decades. But it's also wonderful reading for its seamless movement between global issues, individual farmer-based vignettes, and fictional writings on the "character" of food in our society's story. 